\title{
DIAGNOSING THE EFFECTS OF LEADER-MEMBER EXCHANGE QUALITY ON PERFORMANCE IN THE CONTEXT OF ORGANIZATIONAL CULTURE: A CASE FROM TURKISH FAMILY-OWNED BUSINESSES
}

\author{
Nazli Ayse Ayyildiz Unnu1, Julide Kesken² \\ Department of Business Administration, Faculty of Economics \\ and Administrative Ege University, Sciences, Izmir, Turkey \\ E-mails: ${ }^{1}$ nazliayse.ayyildiz@ege.edu.tr (correspondingauthor);2 julide.kesken@ege.edu.tr
}

Received 19 September 2011; accepted 28 December 2011

\begin{abstract}
The main purpose of this study was to diagnose the effects of leader-member exchange (LMX) quality on performance in the context of organizational and Turkish culture. The study was conducted in two family-owned businesses (FOBs), as they are very important structures in which in-group and out-group formations can be seen. Firm A (33 employees representing 41 dyads) and Firm B (61 employees representing 60 dyads) were especially chosen as they enabled us to apply the coding system leading to effective evaluation of surveys as the unit of analysis is "dyads". In this framework, this study offers an important contribution to the international management literature as positive effects of LMX quality on firm performance, subordinate performance, intention to leave and job satisfaction were found within the context of organizational and Turkish culture. As the proportion of FOBs is almost 95\% in Turkey, they represent Turkish economy and business culture well, leading to more generalizable results. Thus, firms can lead to increase in both subordinate and firm performance by creating an organizational culture in which high quality leader-member relationships are emphasized, finally leading to positive organizational outcomes.
\end{abstract}

Keywords: leader-member exchange theory, family-owned businesses, organizational culture, Turkish culture, organizational performance, subordinate performance.

Reference to this paper should be made as follows: Unnu, N. A. A.; Kesken, J. 2014. Diagnosing the effects of leader-member echange quality on performance in the context of organizational culture: a case from Turkish family-owned business, Journal of Business Economics and Management 15(1): 174-195.

JEL Classification: M14, M19.

\section{Introduction}

The aim of this paper is to find out the foreseen effects of LMX quality on both firm performance and subordinate performance by taking the effect of organizational culture into consideration. There are several studies exploring the effects of LMX quality on organizational dynamics in Turkish organizations (e.g. Erdogan et al. 2004, 2006; Cevrioglu 2007; Ozutku et al. 2007; Pellegrini, Scandura 2006; Erdogan, Liden 2006; 
Karcioglu, Kahya 2011; Sahin 2011; Cetin et al. 2012). Some of these studies were held only at one organization and the effect of organizational culture has not been taken into consideration. Besides, both in Turkey and existing literature the importance of dyads as a unit of analysis is also not taken into account. In literature, exchange quality has been generally evaluated by taking only one side's (only the leader's or the member's) view into consideration. This is against the nature of exchange, which is a process involving both leaders and members. Besides, when only one side's ideas are considered, the differences between the perceptions of leaders and members are neglected. In this context, the effects of perceptional differences on organizational results cannot be evaluated. The number of studies considering both sides' perceptions are very limited (e.g. Erdogan et al. 2006; Maslyn, Uhl-Bien 2001).

Thus, we consider both leaders' and members' perspectives in order to find out the extent of fit between two parties' perceptions. Besides, the subordinate's performance was evaluated both by the subordinate and his/her leader to eliminate biases regarding perceptional differences.

\section{Leader-member exchange theory}

Leadership is the ability to influence, motivate and enable others to contribute to the effectiveness of their organizations (House, Javidan 2004). Graen and Uhl-Bien (1995) highlights that leadership has three main dimensions "leaders, members and the relationship between them". In this context leadership should not be considered as only related with "leaders" or only related with "members". The relationship between the leaders and the members should be also explored in order to understand the leadership process.

Leader-Member Exchange Theory proposed by Graen and his colleagues (Graen, Cashman 1975; Graen 1976; Graen, Scandura 1987) attempts to explain the relationship that develops between supervisors and subordinates as a result of their work place interaction. This theory is concerned with the hierarchical relationship between a supervisor and his/her subordinates (Varma, Stroh 2001) and each leader-member pair is called as "dyad."

Leader-Member Exchange Theory suggests that leaders do not use the same style in dealing with all subordinates, but rather develop a different type of relationship or exchange with each subordinate (Dansereau et al. 1975; Graen, Cashman 1975; Liden, Graen 1980; Graen et al. 1982; Graen, Scandura 1987). These relationships range from those that are based strictly on employment contracts (i.e., low LMX, or "out-group") to those that are characterized by mutual trust, respect, liking and reciprocal influence (i.e. high LMX or "in-group"; Dansereau et al. 1975; Liden, Maslyn 1998). In Figure 1, the in-group and out-group interactions, which are formed regarding the relationship types, can be seen. 


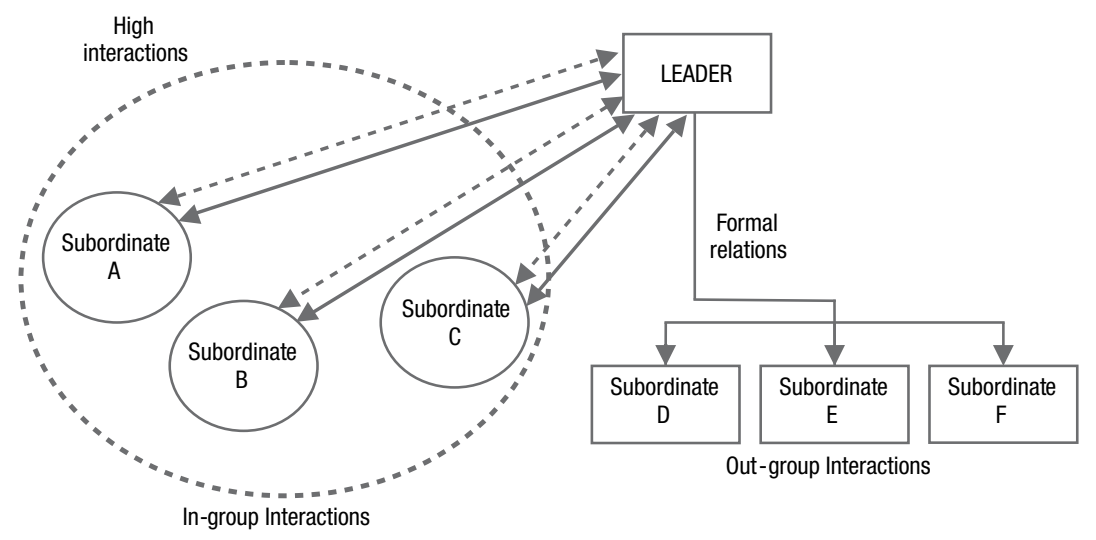

Fig. 1. Leader-Member Exchange Theory

Source: Based on Robbins (2005)

\subsection{Dimensions of leader-member exchange quality}

According to us, LMX should be considered as a multidimensional concept. In this context, it becomes important to identify the dimensions, which the LMX relationship can be categorized. In the existing literature, LMX has been characterized in terms of (a) degree of trust between leader and member (Liden, Graen 1980); (b) subordinate competence (Liden, Graen 1980); (c) degree of loyalty between leader and member (Dansereau et al. 1975); (d) degree of perceived equity of exchange in the relationship by both leader and member (Hollander 1980; Jacobs 1970); (e) degree of mutual influence (Yukl 1981); and (f) amount of interpersonal attraction (or affect) between leader and member (e.g. Dansereau et al. 1975; Graen, Cashman 1975; Tjosvold 1984; Dienesch, Liden 1986).

Mutuality, one basic concept of social exchange theory as applied to leadership, provides us the theoretical focus needed to organize this list. Mutuality implies that an exchange must develop along dimensions to which both parties can contribute and that are valued by both parties (Dienesch, Liden 1986). Three dimensions of the above list have been identified, which fit this definition of mutuality: (a) Perceived Contribution to the exchange - perception of the amount, direction, and quality of work-oriented activity each member puts forth toward the mutual goals (explicit or implicit) of the dyad; (b) Loyalty - the expression of public support for the goals and the personal character of the other member of the LMX dyad; (c) Affect - the mutual affection members of the dyad have for each other based primarily on interpersonal attraction rather than work or professional values (Dienesch, Liden 1986).

Besides, Liden and Maslyn (1998) added a new dimension to Dienesch and Liden's (1986) dimensions "professional respect". It can be defined as the perception of the degree to which each member of the dyad has built a reputation, within and/or outside the organization, of excelling at his or her line of work. This perception may be based on historical data concerning the person, such as; personal experience with the individual, 
comments made about the person from individuals within or outside the organization, and awards or other professional recognition achieved by the person (Liden, Maslyn 1998). There are also other dimensions mentioned in literature such as openness, trust, and honesty. However, in our study, we focus on the four dimensions mentioned above and evaluate each dimensions' effect on LMX quality.

\subsection{Understanding leader-member exchange relationship and related variables in the context of leader-member-exchange quality model}

\subsubsection{Organizational culture}

An organization's culture determines the organization's values, norms and informal activities (Pettigrew 1979; Katz, Kahn 1978). In this manner, studies on organizational culture should not be conducted independent of leadership, as leaders play great role especially in development and dispersion of organizational culture. Besides, organizational culture affects the development of leadership, LMX and the relevance of LMX dimensions. In short, organizational culture embraces the contextual factors such as work groups, organizational politics affecting leadership and LMX. In this regard, it becomes significant to focus on the relationship between LMX and organizational culture and these two concepts should not be explored seperately.

Based on the leadership-culture research published thus far, the following tentative conclusions have been suggested by researchers (Block 2003): The impact of leadership on firm performance is mediated by organizational culture (Ogbonna, Harris 2000). Leadership creates an environment in which fundamental organizational change is more or less likely to occur (Hennessey 1998). Specific leadership behaviors are associated with distinct cultural traits (Lok, Crawford 1999). Contextual factors such as organizational culture have an impact on the emergence of specific leadership styles (Pillai, Meindl 1998). Leaders use their knowledge of organizational culture to affect change (Brooks 1996). The behaviors of leaders influence the perceptions of organizational culture among followers (Chodkowski 1999).

When the existing literature is explored, it is seen that there are limited number of studies exploring the relationship between LMX and organizational culture (e.g. Herrera et al. 2013; Erdogan, Liden 2006; Erdogan et al. 2006; Yu, Liang 2004). As organizational culture includes leadership styles, the nature of relationship between leaders and members should be also considered. Thus, we explore the foreseen correlations by referring to Turkish culture as organization's culture is affected by the national culture. For example Ouchi (1981) has identified that in Japanese and American organizations commitment and loyalty dimensions are significant. In this study, we aim to find out the dimensions regarding LMX highlighted in Turkish organizational context.

\subsubsection{Firm performance}

Another variable that is explored in our study is firm performance. In literature, organizational culture is mentioned as an important factor affecting firm performance (Cameron, Ettington 1988; Denison 1990; Trice, Beyer 1993). Besides, culture also plays an essential role in long-term financial success. It also has effects on individual 
dynamics such as commitment, productivity, physical and emotional health of workforce (Kozlowski et al. 1993). In this regard organizational culture should be explored by leaders and managers thoroughly.

We aimed to explore the relationships between LMX and performance in the context of organizational culture, as culture guides the search for and interpretation of information through schemas (Harris 1994). An organization's members pay more attention to the presence and absence of behaviors that are at the core of its culture. Besides, culture acts as a social control mechanism (O'Reilly, Chatman 1996) and frames people's interpretations of organizational events and processes (Sorensen 2002). Deviations from cultural norms are soon noticed and corrected. Thus, if culture emphasizes relationship development, individuals feel motivated to form high-quality leader-member exchanges, even in the presence of factors that are associated with low-quality exchanges (Erdogan et al. 2006).

Socialization process, which is a sub-system of organizational culture, is also considered when the relationship between LMX and performance is explored. In this context, we consider tenure of employees as we interpret the results. We think that the new members of the organization will have lower levels of LMX. Besides, if the organizational culture emphasizes the importance of performance, the socialized behavior will create more bonds with both other members and leaders and lead to increase in performance levels. When organizational culture is studied, the sub-cultures should be also taken into account. As we explore the organizational culture in FOBs, we think that it becomes vital to explore sub-cultures. In this context, FOBs, embracing both family members and professionals, will have different cultural chararacteriscs leading to different levels of LMX quality. Thus, following hypotheses are identified.

H1: LMX (rated both by subordinate and supervisor) and firm performance are positively related.

H2: Organizational culture is positively related to LMX quality.

H3: Organizational culture has effects on firm performance.

H4: Organizational culture has effects on subordinate performance.

\subsubsection{Job satisfaction and intention to leave}

In order to find out the effects of LMX on firm performance thoroughly, we also determined that job satisfaction and intention to leave can be indicators of firm performance. Thus, the relationship between these variables were also considered in the context of the research model.

The level of job satisfaction has been accepted as an important performance indicator as well as financial performance indicators. Most of the firms are aware of the fact that satisfied employees will perform better, leading to better financial performance eventually (Rust et al. 1996; Agca 2005).

Schriesheim et al. (1998) found out that LMX from both subordinates' and supervisors' viewpoints were shown to be significant correlates of job satisfaction on 106 dyads. 
Janssen and Van Yperen (2004) collected data from 170 employees of a Dutch firm and found out that the quality of LMX mediated positive relationships between mastery orientation and leader-rated in-role job performance, leader-rated innovative job performance, and job satisfaction. Results based on a sample of 439 employees, who completed the study questionnaires at 2 time points, showed that the there was a positive and significant relationship between LMX and job satisfaction (Epitropaki, Martin 2005).

Regarding these findings in literature, it is seen that LMX plays significant role in shaping employee attitudes, such as job satisfaction (e.g. Major et al. 1995 in Epitropaki, Martin 2005). Thus, it is predicted that higher LMX quality will lead to higher job satisfaction leading to higher subordinate performance. Higher subordinate performance will finally lead to higher firm performance as shown in our research model.

In most of the studies, it is found out that LMX quality is negatively and significantly related to intention to leave (Ferris 1985; Gerstner, Day 1997; Graen et al. 1982; Vecchio, Gobdel 1984; Wilhelm et al. 1993). Intention to leave is taken both as a performance criteria and indicator of performance (Robbins 2005). Thus, the relationship between LMX and intention to leave has also been considered within the context of our research model. When the literature regarding the relationship between LMX and intention to leave is analysed thoroughly, it is seen that some of the researchers found out a negative, linear relationship between two variables (Vecchio, Gobdel 1984; Wilhelm et al. 1993), whereas Harris et al. (2005) found a non-linear relationship. In a study, which is conducted in Turkey by Cevrioglu (2007), it is found out that LMX quality is negatively and significantly related to intention to leave.

The reason lying behind the emphasis on intention to leave rather than turnover rate in the context of research is the fact that there is nothing to do for the actual turnover rates. However, if the intentions to leave within the organization can be diagnosed, then some precautions, such as attitudes leading to higher LMX quality, can be taken. Besides, the employees with intention to leave tend to affect other employees in a negative way leading to negative impacts on business processes (Griffeth et al. 2000; Harris et al. 2005).

H5: LMX (rated both by subordinate and supervisor) is positively related to subordinate job satisfaction.

H6: LMX (rated both by subordinate and supervisor) is negatively related to subordinate's intention to leave.

\subsubsection{Subordinate performance}

Considerable research has examined the relationship between LMX quality and individual performance (Erdogan, Liden 2002; Liden et al. 1997). The quality of leadermember relationships, in turn, is assumed to reflect the extent to which the leader and subordinate exchange resources and support beyond what is expected based on the formal employment contract (Dansereau et al. 1975), thus leading to a relationship between LMX quality and subordinate performance. 
Despite extensive research on LMX quality and individual performance (Gerstner, Day 1997; Graen, Uhl-Bien 1995; Liden et al. 2006; Wayne et al. 1997) substantially inconsistent results were found regarding the relationship between two variables (Bauer et al. 2006; Jensen et al. 1997; Vecchio, Gobdel 1984; Wayne et al. 1997). In some of the research results, a positive relationship between LMX and subordinate performance has been found (e.g. Dansereau et al. 1975; Deluga, Perry 1994; Dockery, Steiner 1990) whereas statistically weak (Rosse, Kraut 1983) or insignificant relationships has been found between two variables in other research results (e.g. Liden et al. 1993). The inconsistent relationship between LMX quality and subordinate performance may be the result of two factors: Firstly, most studies reporting significant relationships use subjective measures of performance whereas most studies reporting weak or nonsignificant relationships use objective measures (Jensen et al. 1997; Liden et al. 1997). Secondly, few investigations examine the possibility that moderating variables could be affecting the link between LMX quality and performance (Vecchio, Gobdel 1984), but those adopting a contingency approach often find significant relationships (e.g. Dunegan et al. 1992, 2002; Graen et al. 1982).

Dunegan et al. (2002) have taken role conflict, role ambiguity and intrinsic task satisfaction as moderators and found out that these variables moderate the relationship between LMX quality and subordinate performance. In another study conducted by Dunegan et al. (1992), the relationship between LMX quality and subordinate performance is found to be moderated by task analyzability and variety. In another study, it has been found that work structure has an important effect on the relationship between LMX quality and performance (Jensen et al. 1997). As well as these stuedies the effects of LMX differentiation on individual and group performance were investigated with a sample of 120 work groups consisting of 834 employees (Liden et al. 2006). The results demonstrated that LMX quality moderated the relationship between LMX differentiation and individual performance, such that increases in LMX differentiation were accompanied by increases in individual performance for low LMX members, but no change in individual performance for high LMX members. Schriesheim et al. (1998) examined subordinate and supervisor LMX quality as correlates of delegation and as moderators of relationships between delegation, subordinate performance and satisfaction. Analysis of data on 106 dyads showed both to be significantly related to delegation and to have similar main and moderating effects for subordinate performance and satisfaction. In relation to literature review above, following hypothesis has been identified.

H7: LMX (rated both by subordinate and supervisor) is positively related to subordinate performance.

\subsubsection{Tenure}

There are many studies which have taken tenure as a moderating variable in the relationship between LMX quality and performance. Masterson et al. (2000) found a positive and significant relationship between LMX quality and performance in a study, which focused on university staff, who had been working more than seven years. Similarly, Wayne et al. (1997) conducted a study on employees who had been working at least 
five years in the organization and found a positive and significant relationship between LMX quality and performance.

Within the context of this research, both the organizational tenure and dyadic tenure are taken into account. Organizational tenure refers to the period spent within the organization, whereas dyadic tenure is the period spent together with the subordinate/supervisor. Thus, the following hypotheses have been identified in relation to literature review:

H8: Organizational tenure moderates the relationship between LMX and subordinate performance such that LMX quality is more strongly related to subordinate performance of members whose organizational tenure is higher than those whose tenure is low.

H8a: Dyadic tenure moderates the relationship between LMX and subordinate performance such that LMX quality is more strongly related to subordinate performance of members whose dyadic tenure is higher than those whose tenure is low.

\section{Methodology}

In the literature there are inconsistent views regarding the analysis and assessment of LMX quality. It was most often assessed from the followers' perspective and then related to antecedents or outcomes. However, as we can understand from the term "exchange", it is an interaction process which includes both leader and member. Besides, leaders tend to say that they behave in a same way to all of their subordinates even they do not (Scandura et al. 1986). In this context, most of the researchers agree upon taking the perceptions of both supervisors and subordinates into consideration when LMX quality is evaluated (Gerstner, Day 1997; Greguras, Ford 2006; Scandura, Schriesheim 1994; Schriesheim et al. 1998).

Besides, the subordinate performance should be also measured by taking both parties' views into consideration, as there can be a difference between the self appraisal of performance by the subordinate and evaluation of the performance by the supervisor. The "status" of the both supervisor and subordinate is also taken into consideration within the context of proposed research model (Fig. 2), as views regarding LMX quality may change depending on the it (status: whether the respondent is a family member or a professional employee).

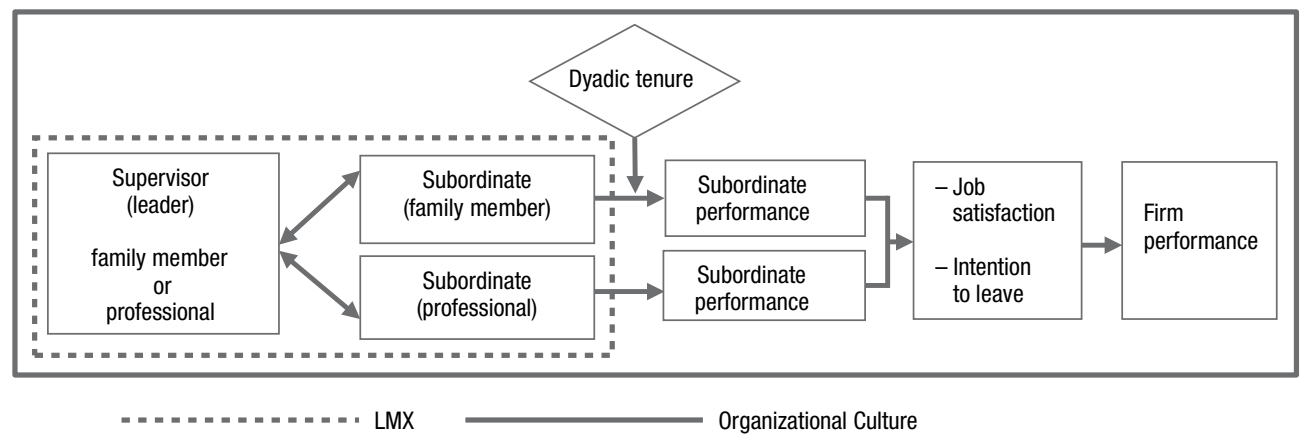

Fig. 2. Proposed research model 


\subsection{Sample and procedures}

Data were collected using surveys distributed in two FOBs in Izmir, Turkey. 94 employees representing 101 dyads answered 202 surveys. The reasons lying behind the selection of two FOBs can be summarized as follows: (a) In most of the studies LMX quality has not been evaluated within the context of FOBs (e.g. Murphy et al. 2003). However, the possibility of seeing in-group and out-group formations is higher in FOBs as they comprise both family members and professional members. (b) Besides, the proportion of FOBs is almost $95 \%$ in Turkey and they represent Turkish economy and business culture well, leading to more generalizable results. (c) Firm A and Firm B were especially chosen as the top management of these two firms guaranteed us that we will be able to get in touch with all of the supervisors and subordinates leading to a wide network of interactions. (d) The most important of all, the firms enabled us to apply the "coding system" leading to effective evaluation of surveys as the unit of analysis is dyads. In order to do that, before distributing the surveys we conducted interviews that enable us to expose relationship networks. Finally, the leader-member dyads were exposed and the surveys were implicitly coded.

Firm $A$ is a manufacturing company, which had 146 employees in total. 21 of the employees were white-collar, whereas 125 of the employees were blue-collar. All of the white-collar employees were surveyed, whereas 12 of the blue-collar workers were surveyed. We had chosen those 12 workers after an interview with the direct supervisors of them. Finally, we surveyed 33 employess representing 41 dyads in total. The number of dyads we can reach was low due to the work load of blue-collar workers. In this regard, the response rate was $23 \%$. Firm B is a company operating at service sector, which had 75 employees in total. Its headquarters was located in Izmir (the third biggest city of Turkey). 145 respondents were working in Izmir. Other respondents were working at different branches located in two different cities "Bodrum" and "Milas". We surveyed all the employees in the headquarters of the company (Izmir) and Bodrum (branch). 61 employess representing 60 dyads in total were surveyed. In this regard, the response rate was $81 \%$.

In Firm A, of the respondents who provided demographic information, 8 were female and 25 were male, whereas 11 were female and 50 were male in Firm B. 3 of the respondents were family members, whereas 30 of them were professional members in Firm A. In Firm B, 6 of the respondents were family members, whereas 55 of them were professional members.

\subsection{Data collection}

The surveys were distributed face to face in order to increase the response rate in both companies during normal working hours. Before distributing the surveys, short information was given to each respondent regarding the parts in the survey. The completed surveys were collected from each participant within a closed envelope to ensure that the answers would be kept secret and it was told that upper-level management would only receive summarized data. 
Two surveys, that were designed for subordinates and supervisors were used. The subordinates' survey contained measures for organizational culture, LMX quality, demographic variables, self appraisal of performance, job satisfaction and intention to leave. The supervisors' survey contained measures for organizational culture, LMX quality, demographic variables, supervisor rated subordinate performance, job satisfaction and intention to leave. In supervisors' survey there is a distinct part, in which questions regarding firm performance were asked. However, the survey with this distinct part was only distributed to the members of top management team.

\subsection{Questionnaire and measures}

Surveys were administered in Turkish. The entire questionnaires were translated from English to Turkish by a Turkish professor, whose interest area is management and organization. The translated version was then back-translated to English by a Turkish employee with work experience and MBA graduate degree. The two translators then met to resolve the discrepancies. The final Turkish survey was then given to two bilingual academicians, who answered both the English and the Turkish versions of the survey and inspected the content equivalence of items and they agreed upon the final version of the survey. In a pilot study, 30 universtiy members (15 dyads) and 20 employees (10 dyads) from a manufacturing company, that were not part of the study, completed the surveys to check the clarity of items. These respondents encountered a few problems when completing the surveys. Thus, the problems were eliminated based on their suggestions to make the surveys clearer.

Organizational culture assessment instrument (OCAI): There are differences in terms of the potential of the instruments to explore the deeper manifestations of culture. All of them examine employee perceptions and opinions about their working environment but only a few, such as Competing Values Framework examine the values and beliefs that inform of those views (Scott et al. 2003). Thus, OCAI developed by Cameron and Quinn (1999), which is based on Competing Values Framework, was used to diagnose the perceived and preferred organizational culture.

Leader member exchange quality measure: LMX quality was measured by taking both supervisors and subordinates ratings into account to avoid "common source bias" and it is mentioned as "general LMX quality" in findings and discussion parts.

LMX-MDM: The subordinate perceptions of the LMX quality were assessed with the LMX-MDM (Liden, Maslyn 1998). This scale consists of 12 items that measure four dimensions: affect, loyalty, contribution, and professional respect. All item responses were scaled from 1-strongly agree to 5-strongly disagree. It should be noted that the original LMX-MDM scale used a 7-point scale (with the same anchors). We chose to use a 5-point scale for consistency in response scales with the other attitude scales (Greguras, Ford 2006).

SLMX-MDM: Supervisor perceptions of LMX quality were measured using a parallel form of Liden and Maslyn's (1998) LMX-MDM, which consisted of minor adaptations intended to transform items from the subordinate's perspective to the supervisor's (the 
word supervisor was changed to subordinate). However, the resultant items are not "mirrors" of one another in that they measure a different aspect of the exchange relationship. One item from the LMX-affect scale is: "I like my supervisor very much as a person". Rather than creating a mirrored item (My subordinate likes me very much as a person), Greguras and Ford (2006) created a paralleled item (I like my subordinate very much as a person). Consistent with LMX-MDM in the current study, all item responses ranged from 1-strongly agree to 5-strongly disagree.

Subordinate performance measure: Subordinate performance was measured by taking both supervisors and subordinates ratings into account to avoid "common source bias". Scores on both measures were averaged to yield a summary score reflecting subordinate performance and it is mentioned as "general subordinate performance" in findings and discussion parts.

Self-appraisal of subordinate performance: Subordinate performance was measured using a self-appraisal approach. Two dimensions of performance, namely quality of performance and productivity were measured using four items. The first two items assess quality of performance and productivity of the individuals on their jobs, while the remaining two items assess individuals' quality of performance and productivity compared with others doing similar jobs. A five-point scale was employed ranging, from 1 (very high) to 5 (very low). Scores on the four items were averaged to yield a summary score reflecting subordinate performance. The self-appraisal approach, adopted in this study, has been used previously by Al-Gattan (1983), Stevens et al. (1978), Ozutku et al. (2007), Cevrioglu (2007) and yielded acceptable outcomes.

Appraisal of subordinate performance by the supervisor: We measured subordinate performance using Podsakoff and MacKenzie's (1989) five-item scale for in-role job performance. Welbourne et al. (1998), Bauer et al. (2006), and Janssen and Van Yperen (2004) had also used this scale to find out the relationship between LMX quality and subordinate performance. The immediate supervisors of the respondents indicated the extent to which they agreed or disagreed with five statements about the quality and quantity of the respondents' activities (1, "strongly agree" to 5, "strongly disagree").

Firm performance: we measured firm performance by asking about the increase level in the following indicators (on the basis of last 1 year): profitability, increase in sales volume, increase in market share, increase in number of employees. A 5-point scale was used (1, "increased a lot" to 5, "decreased a lot"). Besides, job satisfaction and intention to leave had been also taken into consideration as managerial performance indicators while interpreting the results.

Job satisfaction: job satisfaction was measured by a single-item question with a 5-point scale. "I am satisfied with my job (1, "strongly agree," to 5, "strongly disagree”).

Intention to leave: the intention to leave was assessed with a scale, which is developed by Landau and Hammer (1986). This 5-point scale consists of 3 items "I am actively looking for a job outside, As soon as I can find a better job, I will leave the company, I am seriously thinking about quitting my job" (1, "strongly agree" to 5, "strongly disagree”). Wayne et al. (1997) and Bauer et al. (2006) also used this scale for their studies regarding LMX quality. 


\section{Findings and discussions}

As we mentioned before, we had conducted our research on two FOBs. In both results and discussion part, we both share the general results gained from the total data including Firm A and Firm B and spesific results regarding each firm. Besides, we refer to general LMX quality (rated both by subordinate and supervisor) and general subordinate performance (rated both by subordinate and supervisor) in findings and discussion part.

The LMX quality was found high in both firms. This result can be explained by taking the effects of national culture on organizations into account. Turkish culture has high scores in collectivism dimension. Thus; the relationships in such a cultural context is generally close and family-type. Responsibility and loyalty are important characteristics in such cultures, which may lead to formation of high quality relationships. According to collectivists, relationships have a normative dimension, whereas individualists put emphasis on operational dimension of relationships (Bodur, Kabasakal 2002; Hofstede et al. 1990).

Differences regarding LMX quality were found between the ratings of subordinates $(\bar{X}=1.95)$ and supervisors $(\bar{X}=2.30)$. Thus, these results justified our views that LMX quality should be measured by taking both parties' perceptions into account.

In Firm A contribution dimension has the highest score, whereas in Firm B professional respect has the highest score. The reason underlying that result can be explained by taking the effects of tenure and organizational age into account. Firm A was founded in 1993 and managed by both first and second generations, whereas Firm B was founded in 1942 and managed by both second and third generations. Thus, as Firm B is longestablished and its organizational tenure is higher, it might have overcome issues regarding affect, contribution and loyalty and prefer to focus on professional respect based on competency, ability and knowledge. In total, contribution score has the highest score. In this regard, both supervisors and subordinates should work for their dyadic partner that goes beyond what is specified in the job description, apply extra efforts beyond those normally required to meet the partner's goals and not mind working hard for the dyadic partner. Thus, contribution dimension will enhance, leading to higher quality of LMX.

In both firms a positive and a significant relationship has been found between LMX quality and subordinate performance. In order to enable a general and summarized review, the results regarding the relationship between general LMX and general subordinate performance were highlighted at first. Thus, a positive and a significant relationship between two variables has been found $(\mathrm{r}=0.671 ; \mathrm{p}<0.01)$. These findings are consistent with the studies in literature (Dansereau et al. 1975; Deluga, Perry 1994; Dockery, Steiner 1990; Gerstner, Day 1997; Rosse, Kraut 1983). Besides, it was found that general LMX has positive and significant effects on subordinate performance $(\mathrm{t}=$ 8.906; $\left.\mathrm{p}=0.000 ; \mathrm{R}^{2}=0.44\right)$. It explains $44.4 \%$ of the total variation in subordinate performance. The Correlation and Regression analyses supported Hypothesis 7. Thus, the first step of our research model is supported.

When we analysed the effects of subdimensions of LMX quality on general subordinate performance, it is found out that in Firm A all dimensions have positive and significant 
effect on subordinate performance. The total variations in subordinate performance, explained by each subdimension, are as follows: Affect, $45 \%$; professional respect, $35 \%$; loyalty, 33\%; contribution, 27\%. Thus, Firm A needs to emphasize "affect" dimension in order to enhance subordinate performance via LMX quality. Besides, in Firm B all dimensions have positive and significant effect on subordinate performance. The total variations in subordinate performance, explained by each subdimension, are as follows: contribution, 53\%; affect, 40\%; professional respect, $29 \%$; loyalty, $18 \%$ ). Thus, Firm B needs to emphasize "contribution" dimension in order to enhance subordinate performance via LMX quality.

FOBs have different characteristics in comparison with other firms. Besides, they play essential role in national economies. We conducted our analysis on FOBs as they comprise both family members and professional members and we proposed that the perceptions of both subordinates and supervisors might change on the basis of being a family member or not. In order to test our proposition, we conducted independent samples Ttest to examine the differences in study variables and found out that there were not any significant differences among statements regarding LMX quality. Regarding this finding, it can be said that there are no problems such as nepotism and discrimination in these firms, which are mostly seen in many FOBs. Besides we used multivariate analysis of variance (MANOVA) to examine the differences regarding the effect of LMX quality on subordinate performance based on the status of the subordinate /supervisor and no differences were found (Wilks' Lambda $=0.984 ; \mathrm{F}=1.620 ; \mathrm{p}=0.201$ ).

The relationship between LMX quality and firm performance had been also analysed to test the research model. When the relationship between LMX quality based on subordinate perceptions and firm performance were analysed, we found no significant relationship, however when the relationship between LMX quality based on supervisor perceptions and firm performance were analysed, we found a positive and a significant relationship $(\mathrm{r}=0.267 ; \mathrm{p}<.01)$. This finding also emphasizes the importance of taking both parties' perceptions into account when examining the LMX quality. Besides, when the relationship between subdimensions of LMX quality and firm performance were analysed, it is found out that there is a positive and a significant relationship between contribution dimension and firm performance considering the general results $(r=0.203$; $\mathrm{p}<0.05$ ). We also analysed the relationship between subdimensions of LMX quality and general firm performance in both firms. It is found out that in Firm A contribution dimension rated by supervisor is positively related with firm performance $(r=0.326$; $\mathrm{p}<0.05$ ). Besides, in Firm B a positive and a significant relationship has been found between contribution dimension rated by supervisor and firm performance $(\mathrm{r}=0.401$; $\mathrm{p}<0.01)$. Thus, we can say that Hypothesis 1 is supported.

If we had focused only on general LMX quality, instead of analysing the effects of each subdimension, we would have neglected the correlations between LMX quality and firm performance. This would finally lead to a misinterpretation of data. Thus, firm performance can be enhanced by emphasizing contribution dimension in relationships via doing work for supervisor/subordinate that goes beyond what is specified job description, providing extra support and resources, applying extra efforts beyond those normally required to meet work goals and working harder for supervisor/subordinate. 
We conducted regression analysis to find out the effects of general LMX quality on job satisfaction and intention to leave and found out that general LMX quality has a significant and positive effect on job satisfaction $(6 \%$ of the total variation in job satisfaction is explained; $\mathrm{F}=6.9 ; \mathrm{p}<0.05$ and $\mathrm{t}=2.62 ; \mathrm{p}<0.05)$, whereas it has negative and significant effect on intention to leave $(29 \%$ of the total variation in intention to leave is explained; $\mathrm{F}=84.335 ; \mathrm{p}<0,05$ and $\mathrm{t}=-9.183$; $\mathrm{p}<0.05)$. In Firm A a positive and a significant relationship has been found between LMX quality and job satisfaction $(\mathrm{r}=0.221 ; \mathrm{p}<0.05)$, whereas a negative and a significant relationship has been found between LMX quality and intention to leave $(r=-0.442 ; p<0.01)$. Similarly in Firm $\mathrm{B}$, a positive and a significant relationship has been found between LMX quality and job satisfaction $(r=0.514 ; \mathrm{p}<0.01)$, whereas a negative and a significant relationship has been found between LMX quality and intention to leave $(\mathrm{r}=-0.536 ; \mathrm{p}<0.01)$.

In order to enable a general and summarized review, the results gained from the total data regarding the relationship between general LMX quality, job satisfaction and intention to leave were also highlighted. Thus, a positive and a significant relationship between LMX quality and job satisfaction has been found $(r=0.398 ; p<0.01)$, whereas a negative and a significant relationship has been found between LMX quality and intention to leave $(\mathrm{r}=-0.546 \mathrm{p}<0.01)$. Thus, both Hypothesis 5 and Hypothesis 6 are supported.

We also analysed whether if job satisfaction and intention to leave had effects on firm performance via multivariate regression analysis and found out that both variables had effects on it $(F=9.468$, degrees of freedom $=2 ; p=0.00<0.05)$. When the correlations and partial correlations were analysed, it was found out that both variables explain $15 \%$ of the total variation in firm performance. We conducted correlation analysis to find out whether there is a relationship between subordinate and firm performance and found out no significant relationship. However, regression analysis was also conducted to find out the effects of subordinate performance on firm performance and it was found out that subordinate performance had effects on firm performance and explains $5 \%$ of the total variation in it.

We conducted correlation analysis to find out whether there is a relationship between subordinate performance and job satisfaction and found out that there was a positive and a significant relationship between two variables $(r=0.233 ; p<0.05)$. Besides we searched for the relationship between subordinate performance and intention to leave and found out that there was a negative and a significant relationship between two variables $(\mathrm{r}=-0.476 ; \mathrm{p}<0.01)$. Thus, we can say that the second part of our research model, which proposed a relationship between subordinate performance and firm performance was supported from the perspective of managerial performance (managerial performance perspective highlights the importance of job satisfaction and intention to leave as important components and indicators of firm performance). Finally, the increase in subordinate performance will lead to an increase job satisfaction and decrease in intention to leave, eventually leading to an increase in firm performance.

As we mentioned before, all of the organizational dynamics emerge within the context of organizational culture. Thus, analysing the effects of organizational culture on each 
variable mentioned in our research model would be helpful to interpret the results effectively.

The relationship between organizational culture and LMX quality was analysed and in Firm A, a significant relationship between all cultural profiles (clan, hierarchy, adhocracy, market) and LMX quality was found. But the relationship between hierarchy culture and LMX quality is stronger when compared with the relationship levels of other cultural profiles and LMX quality. As Firm A is a manufacturing company, formal rules and roles are very important. However, the importance attached to rules and efficiency does not hinder the development of interpersonal relationships as seen from the results. In this regard, in Firm A, LMX quality can be enhanced by emphasizing productivity, efficiency, reliability, smooth manufacturing, formal rules and procedures, which are the essential values and components of hierarchy cultural profile. In Firm B even though the dominant culture was found as hierarchy, it was found out that adhocracy culture has significant effect on LMX quality. As Firm B is a company operating at service sector in a very competitive arena, it is essential for both subordinates and supervisors to be dynamic, risk-taker, innovative and flexible.Thus, as the dominance of adhocracy culture, which emphasizes innovation, creativity and entrepreneurship increases, LMX quality will enhance too. We can say that Hypothesis 2 was supported.

The effects of organizational culture on firm performance were analysed and it was found out that in Firm A only adhocracy culture has effect on firm performance (9\% of the total variation in firm performance is explained), whereas in Firm B both clan $(37 \%$ of the total variation in firm performance is explained) and adhocracy culture $(23 \%$ of the total variation in firm performance is explained) have effects on firm performance. Thus, in order to enhance firm performance in Firm A, a culture which emphasizes innovation, creativity, dynamism, entrepreneurship and risk-orientation should be fostered. In Firm B, besides fostering an adhocracy culture, the values of clan culture such as teamwork, participation, commitment, loyalty, humane work environment should be also fostered in order to initiate a positive change in firm performance. In this regard, Hypothesis 3 was supported.

The effects of organizational culture on subordinate performance was analysed too and it was found out that in both firms adhocracy and market cultures had effects on subordinate performance. When the member characteristics in a market culture are analysed, it is seen that members value competitiveness, diligence, perfectionism, aggressiveness and personal initiative. The leaders are tough, demanding, hard drivers, producers and competitors as such cultural profiles tend to be result-oriented (Cameron, Quinn 1999). In this regard, in such cultures performance of members tend to be high to survive. Similarly, in adhocracy culture high degree of flexibility and individuality, which is supported by an open system promoting the willingness to act, is fostered. It is a dynamic, entrepreneurial and creative place to work, where people stick their necks out and take risks. Leaders are visionary and innovative and success means producing unique and original products and services (Cameron, Quinn 1999). Thus, in such a culture performance of members also tend to be high. In this context, the positive effects of mentioned cultural profiles on subordinate performance is not surprising. In this regard, Hypothesis 4 was supported. 
When the data regarding the relationship between organizational culture and performance had been analysed thoroughly, it was observed that hierarchy culture had no effect on both subordinate performance and firm performance. The reason underlying that result can be explained by taking the characteristics of hierarchy culture into account. Hierarchy culture focuses on internal maintenance and strives for stability and control through clear task setting and enforcement of strict rules. Thus, it tends to adopt a formal approach to relationships where leaders are good coordinators and organizers. This type of culture focuses on economy, standardized rules and operations, control and accountability mechanisms, formality, rationality, order and obedience (Cameron, Quinn 1999; Igo, Skitmore 2006). In such a cultural profile the members might not feel free enough to share their ideas and cannot fully show their potential, leading to lower performance levels.

Within the context of this research, the effects of both the organizational tenure and dyadic tenure on LMX quality were considered. We conducted ANOVA analysis to test whether LMX quality was different based on organizational and dyadic tenure. In this regard, it was found out that the LMX quality increased as the organizational tenure increased. The reason underlying this result can be explained by the socialization of the members. As the time a member spends in the organization increases, the member gets used to the values, norms, attitudes, colleagues and becomes socialized. Thus, the member learns what is expected from him/her and besides he/she knows what to expect leading to a decrease in dissappointment level. Similarly we found out that the LMX quality differentiated based on dyadic tenure. Thus, LMX quality of the members with a dyadic tenure more than 4 years were higher than the ones whose dyadic tenure was less than 4 years. This result was also expected as people get to know each other well as the time they spend together increases. To test the moderating effect of both organizational and dyadic tenure on the relationship between LMX quality and subordinate performence correlation analysis and partial correlation analysis were conducted, respectively and it was found out that both organizational and dyadic tenure did not moderate the LMX quality-subordinate performance relationship as hypothesized. Thus, both Hypothesis 8 and Hypothesis 8 a were rejected.

In literature, it is emphasized that tenure has an important effect on the relationship betweeen LMX quality and subordinate performance. However, our results are inconsistent with the literature. The reason underlying that result can be explained by the fact that both firms are FOBs and they are medium sized. That's why the socialization process tends to last in a shorter time period when compared with the large, international enterprises. In Firm A there were only 21 white-collar members, thus leading to a family-type culture with socialized members. Besides Firm B, as a long-established FOB, was open to communication and had only 75 employees in total, thus leading to socialized members and inconsistent findings with the literature. 


\section{Conclusions, study limitations and future research directions}

The main purpose of this study was to diagnose the effects of LMXquality on performance in the context of organizational culture by taking two FOBs into consideration. A quantitative approach was employed as we think that survey instrument actually reports underlying values and assumptions (culture), not just superficial attitudes or perceptions (climate) regarding LMX quality, organizational culture and other variables. Respondents may be unaware of essential attributes of the mentioned variables until the scenarios and statements on the survey cue them.

In literature LMX quality has been evaluated by many different scales. Some of these scales are unidimensional, whereas some of them are multidimensional. In the context of this research, multidimensional scales were used to evaluate LMX quality. In a few studies (Erdogan et al. 2004; Pellegrini, Scandura 2006) the same scale was used. However, findings regarding subdimensions of LMX quality had not been given in these mentioned studies. These conditions lead to a difficulty in comparing our results with the previous studies in literature. Another limitation of the study is the restriction in generalizability due to industrial differences. Besides; the use of survey followed by series of interviews might better capture individuals' perceptions toward research variables.

Despite its potential limitations, this study offers an important contribution to the international management literature as it has diagnosed the positive effects of LMX quality on both firm and subordinate performance in the context of organizational culture by taking the effect of national culture into consideration. Besides, there is not any study analysing the effect of LMX quality on both subordinate and firm performance in the context of FOBs. However, FOBs are very important structures in which in-group and out-group formations can be seen.

Finally, LMX quality is an important factor affecting job satisfaction, intention to leave, subordinate and firm performance. Thus, firms can lead to an increase in both subordinate and firm performance by creating an organizational culture in which high quality leader-member relationships are emphasized, finally leading to positive organizational outcomes.

\section{References}

Agca, V. 2005. Íc girisimcilik yapisi ve firma performansina etkileri: denizli tekstil sektorondeki firmalarda bir arastırma. Unpublished Doctoral Thesis. Afyonkarahisar Kocatepe Universitesi.

Al-Gattan, A. R. A. 1983. The path-goal theory of leadership: an empirical and longitudinal analysis: Unpublished Doctoral Dissertation. Arizona State University.

Bauer, T. N.; Erdogan, B.; Liden, R. C.; Sandy, J. W. 2006. A longitudinal study of the moderating role of extraversion: leader-member exchange, performance, and turnover during new executive development, Journal of Applied Psychology 91(2): 298-310.

http://dx.doi.org/10.1037/0021-9010.91.2.298

Block, L. 2003. The leadership-culture connection: an exploratory investigation, Leadership and Organization Development Journal 24(6): 318-334. http://dx.doi.org/10.1108/01437730310494293

Bodur, M.; Kabasakal, H. 2002. Turkiye-Arap kumesinde kurumsal kultur, YAD 2(1): 2-22. 
Brooks, I. 1996. Leadership of a cultural change process, Leadership and Organization Development Journal 17(5): 31-37. http://dx.doi.org/10.1108/01437739610127496

Cameron, K. S.; Ettington, D. R. 1988. The conceptual foundations of organizational culture, in J. C. Smart (Ed.). Higher education: handbook of theory and research. Dordrecht: Kluwer Academic Press, 356-396.

Cameron, K. S.; Quinn, R. E. 1999. Diagnosing and changing organizational culture: based on the competing values framework. $1^{\text {st }}$ ed. Reading: Addison-Wesley.

Cetin, Ş.; Korkmaz, M.; Cakmakci, C. 2012. Donusumsel ve etkilesimsel liderlik ile lider-uye etkilesiminin ogretmenlerin orgutsel vatandaslik davranisi uzerindeki etkisi, Kuram ve Uygulamada Ĕ̈itim Yönetimi 18(1): 7-36.

Cevrioglu, E. 2007. Lider uye etkilesimi ile bireysel orgutsel sonuclar arasindaki iliski: ampirik bir inceleme: Unpublished Doctoral Thesis. Afyonkarahisar Kocatepe Universitesi.

Chodkowski, M. 1999. Relationships between leader characteristics, planned change and organizational culture in a dynamic manufacturing environment: Unpublished Doctoral Thesis. Western Michigan University.

Dansereau, F. Jr.; Graen, G.; Haga, W. J. 1975. A vertical dyad linkage approach to leadership within formal organizations: a longitudinal investigation of the role-making process, Organizational Behavior and Human Performance 13: 46-78.

http://dx.doi.org/10.1016/0030-5073(75)90005-7

Deluga, R. J.; Perry, J. T. 1994. The role of subordinate performance and ingratiation in leadermember exchanges, Group and Organization Management 19: 67-86.

http://dx.doi.org/10.1177/1059601194191004

Denison, D. 1990. Corporate culture and organizational effectiveness. NY: Wiley.

Dienesch, R. M.; Liden, R. C. 1986. Leader-member exchange model of leadership: a critique and further development, Academy of Management Review 11: 618-634.

Dockery, T. M.; Steiner, D. D. 1990. The role of the initial interaction in leader-member exchange, Group and Organization Studies 15: 395-413. http://dx.doi.org/10.1177/105960119001500405

Dunegan, K. J.; Duchon, D.; Uhl-Bien, M. 1992. Examining the link between leader-member exchange and subordinate performance: the role of task analyzability and variety as moderators, Journal of Management 18(1): 59-76. http://dx.doi.org/10.1177/014920639201800105

Dunegan, K. J.; Uhl-Bien, M.; Duchon, D. 2002. LMX and subordinate performance: the moderating effects of task characteristics, Journal of Business and Psychology 17(2): 275-285.

http://dx.doi.org/10.1023/A:1019641700724

Epitropaki, O.; Martin, R. 2005. From ideal to real: a longitudinal study of the role of implicit leadership theories on leader-member exchanges and employee outcomes, Journal of Applied Psychology 90(4): 659-676. http://dx.doi.org/10.1037/0021-9010.90.4.659

Erdogan, B.; Kraimer, M. L.; Liden, R. C. 2004. Work value congruence and intrinsic career success: the compensatory roles of leader-member exchange and perceived organizational support, Personnel Psychology 57(2): 305-332. http://dx.doi.org/10.1111/j.1744-6570.2004.tb02493.x

Erdogan, B.; Liden, R. C. 2002. Social exchanges in the workplace: a review of recent developments and future research directions in leader-member exchange theory, in L. L. Neider, C. A. Schriesheim (Eds.). Leadership. Greenwich, CT: Information Age Press, 65-114.

Erdogan, B.; Liden, R. C. 2006. Collectivism as a moderator of responses to organizational justice: implications for leader-member exchange and ingratiation, Journal of Organizational Behavior 27: 1-17. http://dx.doi.org/10.1002/job.365

Erdogan, B.; Liden, R. C.; Kraimer, M. L. 2006. Justice and leader-member exchange: the moderating role of organizational culture, Academy of Management Journal 49(2): 395-406.

http://dx.doi.org/10.5465/AMJ.2006.20786086 
Ferris, G. R. 1985. Role of leadership in the employee withdrawal process: a constructive replication, Journal of Applied Psychology 70: 777-781. http://dx.doi.org/10.1037/0021-9010.70.4.777

Gerstner, C. R.; Day, D. V. 1997. Meta-analytic review of leader-member exchange theory: correlates and construct issues, Journal of Applied Psychology 82: 827-844.

http://dx.doi.org/10.1037/0021-9010.82.6.827

Graen, G. B. 1976. Role-making process within complex organizations, in M. D. Dunnete (Ed.). Handbook of industrial and organizational psychology. Chicago: Rand McNally, 1201-1245.

Graen, G. B.; Cashman, J. F. 1975. A role-making model in formal organizations: a development approach, in J. G. Hunt, L. L. Larson (Eds.). Leadership frontiers. Ohio: Kent State University Press, 143-165.

Graen, G. B.; Liden, R. C.; Hoel, W. 1982. Role of leadership in the employee withdrawal process, Journal of Applied Psychology 67: 868-872. http://dx.doi.org/10.1037/0021-9010.67.6.868

Graen, G. B.; Scandura, T. 1987. Toward a psychology of dyadic organizing, in B. Staw, L. L. Cumming (Eds.). Research in Organizational Behavior. Greenwich, Ct: JAI, 175-208.

Graen, G. B.; Uhl-Bien, M. 1995. Relationship-based approach to leadership: development of leader-member exchange (LMX) theory of leadership over 25 years: applying a multi-level multidomain perspective, The Leadership Quarterly 6(2): 219-247.

http://dx.doi.org/10.1016/1048-9843(95)90036-5

Greguras, G. J.; Ford, J. M. 2006. An examination of the multidimensionality of supervisor and subordinate perceptions of leader-member exchange, Journal of Occupational and Organizational Psychology 79: 433-465. http://dx.doi.org/10.1348/096317905X53859

Griffeth, R. W.; Hom, P. W.; Gaertner, S. 2000. A meta-analysis of antecedents and correlates of employee turnover: update, moderator tests, and research implications for the next millennium, Journal of Management 26: 463-488. http://dx.doi.org/10.1177/014920630002600305

Harris, K. J.; Kacmar, K. M.; Witt, L. A. 2005. An examination of the curvilinear relationship betweenleader-member exchange and intent to turnover, Journal of Organizational Behavior 26: 363-378. http://dx.doi.org/10.1002/job.314

Harris, S. G. 1994. Organizational culture and individual sensemaking: a schema-based perspective, Organization Science 5: 309-321. http://dx.doi.org/10.1287/orsc.5.3.309

Hennessey, J. T. 1998. Reinventing government: does leadership make a difference?, Public Administration Review 58: 322-332. http://dx.doi.org/10.2307/977579

Herrera, R.; Duncan, P.; Ree M. 2013. Aligning organizational culture with leader-member exchange, Global Business and Organizational Excellence July/August 2013: 53-65.

http://dx.doi.org/10.1002/joe.21503

Hofstede, G.; Neuijen, B.; Ohayv, D. D.; Sanders, G. 1990. Measuring organizational cultures: a qualitative and quantitative study across twenty cases, Administrative Science Quartely 35(2): 286-316. http://dx.doi.org/10.2307/2393392

Hollander, E. P. 1980. Leadership and social exchange processes, in K. J. Gergen, M. S. Greenberg, R. H. Willis (Eds.). Social exchange processes. New York: Plenum.

http://dx.doi.org/10.1007/978-1-4613-3087-5_5

House, J. H.; Javidan, M. 2004. Overview of Globe, in R. J. House, P. J. Hanges, M. Javidan, P. W. Dorfman, V. Gupta, (Eds.). Culture, Leadership, and Organizations: the GLOBE Study of 62 Societies. Thousand Oaks: Sage Publications, 9-28.

Igo, T.; Skitmore, M. 2006. Diagnosing the organizational culture of an Australian engineering consultancy using the competing values framework, Construction Innovation 6(2): 121-139.

Jacobs, T. 1970. Leadership and exchange in formal organizations. VA: Human Resources Research Organization. 
Janssen, O.; Van Yperen, N. W. 2004. Employees' goal orientations, the quality of leader-member exchange, and the outcomes of job performance and job satisfaction, Academy of Management Journal 47(3): 368-384. http://dx.doi.org/10.2307/20159587

Jensen, J. L.; Olberding, J. C.; Rodgers, R. 1997. The quality of leader-member exchange (LMX) and member performance: a meta-analytic review, Academy of Management Proceedings 320-324.

Karcioglu, F.; Kahya, C. 2011. Lider-üye etkilesimi ve çatisma yonetim stili iliskisi, Ataturk Universitesi Sosyal Bilimler Enstitusu Dergisi 15(2): 337-352.

Katz, D.; Kahn, R. 1978. The social psychology of organizations. NY: Wiley.

Kozlowski, S. W.; Chao, G. T.; Smith, E. M.; Hedlund, J. 1993. Organizational downsizing: strategies, interventions, and research implications, International Review of Industrial and Organizational Psychology 8: 263-332.

Landau, J.; Hammer, H. T. 1986. Clerical employees' perceptions of intra-organizational career opportunities, Academy of Management Journal 29: 385-404.

http://dx.doi.org/10.2307/256194

Liden, R. C.; Erdogan, B.; Wayne, S. J.; Sparrowe, R. T. 2006. Leader-member exchange, differentiation and task interdependence: implications for individual and group performance, Journal of Organizational Behavior 27(6): 723-746.

Liden, R. C.; Graen, G. 1980. Generalizability of the vertical dyad linkage model of leadership, Academy of Management Journal 23: 451-465. http://dx.doi.org/10.2307/255511

Liden, R. C.; Maslyn, J. M. 1998. Multidimensionality of leader-member exchange: an empirical assessment through scale development, Journal of Management 24(1): 43-72.

Liden, R. C.; Sparrowe, R. T.; Wayne, S. J. 1997. Leader-member exchange theory: the past and potential for the future, in G. Ferris (Ed.). Research in personnel and human resources management. Greenwich, CT: JAI, 47-119.

Liden, R. C.; Wayne, S. J.; Stilwell, D. 1993. A longitudinal study on the early development of leader-member exchanges, Journal of Applied Psychology 78: 662-674.

http://dx.doi.org/10.1037/0021-9010.78.4.662

Lok, P.; Crawford, J. 1999. The relationship between commitment and organizational culture, subculture, leadership style and job satisfaction in organizational change and development, Leadership and Organization Development Journal 20(7): 365-373.

http://dx.doi.org/10.1108/01437739910302524

Major, D. A.; Kozlowski, S. W. J.; Chao, G. T.; Gardner, P. D. 1995. A longitudinal investigation of newcomer expectations, early socialization outcomes, and the moderating effects of role development factors, Journal of Applied Psychology 80: 418-431.

http://dx.doi.org/10.1037/0021-9010.80.3.418

Maslyn, J. M.; Uhl-Bien, M. 2001. Leader-member exchange and its dimensions; effects of selfeffort and other's effort on relationship quality, Journal of Applied Psychology 86(4): 697-708. http://dx.doi.org/10.1037/0021-9010.86.4.697

Masterson, S. S.; Lewis, K.; Goldman, B. M.; Taylor, M. S. 2000. Integrating justice and social exchange: the differing effects of fair procedures and treatment on work relationships, Academy of Management Journal 43: 738-748. http://dx.doi.org/10.2307/1556364

Murphy, S. M.; Wayne, S. J.; Liden, R. C.; Erdogan, B. 2003. Understanding social loafing: the role of justice perceptions and exchange relationships, Human Relations 56(1): 61-84.

http://dx.doi.org/10.1177/0018726703056001450

Ogbonna, E.; Harris, L. 2000. Leadership style, organizational culture and performance: empirical evidence from UK companies, International Journal of Human Resource Management 11(4): 766-788. http://dx.doi.org/10.1080/09585190050075114 
O’Reilly, C.; Chatman, J. A. 1996. Culture as social control: corporations, cults, and commitment, in B. M. Staw, L. Cummings (Eds.). Research in organizational behavior. Stamford, CT.: JAI Press, 287-365.

Ouchi, W. G. 1981. Theory Z: how American business can meet the Japanese challenge. MA: Addison-Wesley.

Ozutku, H.; Agca, V.; Cevrioglu, E. 2007. Lider-uye etkilesimi teorisi cercevesinde yonetici-ast etkilesimi ile orgütsel baglilik boyutlari ve is performansi arasindaki iliski: Ampirik bir inceleme, 15. Ulusal Yonetim ve Organizasyon Kongresi Bildiriler Kitabi. Sakarya Universitesi, 288-295.

Pellegrini, E. K.; Scandura, T. A. 2006. Leader-member exchange (LMX), paternalism and delegation in the Turkish business culture: an empirical investigation, Journal of International Business Studies 37(2): 264-279. http://dx.doi.org/10.1057/palgrave.jibs.8400185

Pettigrew, A. M. 1979. On studying organizational cultures, Administrative Science Quarterly 24: 570-581. http://dx.doi.org/10.2307/2392363

Pillai, R.; Meindl, J. R. 1998. Context and charisma: a meso level approach to the relationship of organic structure, collectivism and crisis to charismatic leadership, Journal of Management 24(5): 643-671.

Podsakoff, P. M.; MacKenzie, S. B. 1989. A second generation measure of organizational citizenship behavior, Working paper. Indiana University, Bloomington.

Robbins, S. P. 2005. Organizational behavior. New Jersey: Prentice Hall.

Rosse, J. G.; Kraut, A. I. 1983. Reconsidering the vertical dyadic linkage model of leadership, Journal of Occupational Psychology 56: 63-71.

http://dx.doi.org/10.1111/j.2044-8325.1983.tb00111.x

Rust, R. T.; Stewart, G. L.; Miller, H.; Pielack, D. 1996. The satisfaction and retention of frontline employees: a customer satisfaction measurement approach, International Journal of Service Industry Management 7(50): 62-80.

Sahin, F. 2011. Lider-uye etkilesimi ile isten ayrilma niyeti arasindaki iliski uzerinde cinsiyetin etkisi [The effect of gender on the relationship between LMX and intention to quit], Ege Academic Review 11(2): 277-288.

Scandura, T. A.; Schriesheim, C. A. 1994. Leader-member exchange and supervisor career mentoring as complementary concepts in leadership research, Academy of Management Journal 37: 1588-1602. http://dx.doi.org/10.2307/256800

Scandura, T. A.; Graen, G. B.; Novak, M. A. 1986. When managers decide not to decide autocratically: an investigation of leader-member exchange and decision influence, Journal of Applied Psychology 71(4): 579-584. http://dx.doi.org/10.1037/0021-9010.71.4.579

Scott, T.; Mannion, R.; Davies, H.; Marshall, M. 2003. The quantitative measurement of organizational culture in health care: a review of the available instruments, Health Services Research 38(3): 923-945. http://dx.doi.org/10.1111/1475-6773.00154

Schriesheim, C. A.; Neider, L.; Scandura, T. A. 1998. Delegation and leader member exchange, Academy of Management Journal 41: 298-318. http://dx.doi.org/10.2307/256909

Sorensen, J. B. 2002. The strength of corporate culture and the reliability of firm performance, Administrative Science Quarterly 47: 70-91. http://dx.doi.org/10.2307/3094891

Stevens, J. M.; Beyer, J. M.; Trice, H. M. 1978. Assessing personal role and organizational predictors of managerial commitment, Academy of Management Journal 21: 380-396.

http://dx.doi.org/10.2307/255721

Tjosvold, D. 1984. Effects of leader warmth and directiveness on subordinate performance on a subsequent task, Journal of Applied Psychology 69: 422-427.

http://dx.doi.org/10.1037/0021-9010.69.3.422 
Trice, H.; Beyer, J. 1993. The cultures of work organizations. Upper Saddle River, NJ: Prentice Hall.

Varma, A.; Stroh, L. K. 2001. The impact of same-sex LMX dyads on performance evaluations, Human Resource Management 40(4): 309-320. http://dx.doi.org/10.1002/hrm.1021

Vecchio, R. P.; Gobdel, B. C. 1984. Vertical dyad linkage model of leadership: problems and prospects, Organizational Behavior and Human Performance 34: 5-20.

http://dx.doi.org/10.1016/0030-5073(84)90035-7

Wayne, S. J.; Shore, L. M.; Liden, R. C. 1997. Perceived organizational support and leadermember exchange: a social exchange perspective, Academy of Management Journal 40: 82-111. http://dx.doi.org/10.2307/257021

Welbourne, T. M.; Johnson, D. E.; Erez, A. 1998. The role-based performance scale: validity analysis of a theory-based measure, Academy of Management Journal 41: 540-555.

http://dx.doi.org/10.2307/256941

Wilhelm, C. C.; Herd, A. M.; Steiner, D. D. 1993. Attributional conflict between managers and subordinates: an investigation of leader-member exchange effects, Journal of Organizational Behavior 14: 531-544. http://dx.doi.org/10.1002/job.4030140603

Yu, D.; Liang, J. 2004. A new model for examining the leader-member exchange (LMX) theory, Human Resource Development International 7: 251-264.

http://dx.doi.org/10.1080/1367886042000243826

Yukl, G. 1981. Leadership in organizations. Englewood Cliffs, NJ: Prentice-Hall.

Nazli Ayse Ayyildiz UNNU got her Master degree from Ege University, Institute of Social Sciences, Department of Business Administration in 2008. After getting her Master degree, she started $\mathrm{PhD}$ program at Ege University, Institute of Social Sciences, Department of Business Administration in the province of Izmir, Turkey. She has been working as an Assistant Professor in Ege University, Faculty of Economics and Administrative Sciences since 2013. She has been also working as "Departmental Coordinator for Erasmus Program" She is the former editorial assistant of Ege Academic Review, an international peer reviewed Journal (www.eab.ege.edu.tr). Her main field of study is Management and Organization. She has presented many papers at both international and national conferences and all of her papers have been published as proceedings. Besides, she has articles published in national and international refereed journals. She and her colleagues got Best Paper Award with the paper titled "Management Fads and Fashion In Turkey: Role of Consulting Firms on Dissemination Process of Strategic Management Tools", presented at International Strategic Management Conference in 2007. She is also the co-author of a book, which is mainly related with postive and negative styles of leadership, named "Öteki Liderlik" (entitled as "The Other Side of Leadership" in English).

Julide KESKEN is a Professor in Ege University, Faculty of Economics and Administrative Sciences, Department of Business Administration. She has been also working as "Dean" of the Faculty since 2012. Besides, she has been working as a Conjunct Professor at Izmir University of Economics and Yasar University located in the province of Izmir in Turkey. Her PhD was on Organizational Politics. Her main field of study is Management and Organization. She has many articles published in national and international journals. She and her colleagues got Best Paper Award with the paper titled "Management Fads and Fashion In Turkey: Role of Consulting Firms on Dissemination Process of Strategic Management Tools", presented at International Strategic Management Conference in 2007. She is the member of Global Awarenees Society International and European Group of Organizational Studies. She is also a member of Ege University, Social Sciences Institute's Board of Directors. Besides, she is the former consultant of Aegean Region Chamber of Industry. She has been carrying out many consultancy assignments for both family-owned businesses and international companies. She is also the author of a book, which is mainly related with postive and negative styles of leadership, named "Öteki Liderlik" (entitled as "The Other Side of Leadership" in English). 